\title{
The Impact of Financial Education Participation on Financial Knowledge and Efficacy: Evidence from the Canadian Financial Capability Survey
}

\author{
David W. Rothwell
}

Shiyou Wu

\author{
David W. Rothwell, PhD, MSW, Assistant Professor, Human Development and Family Sciences, \\ Oregon State University, 460 Waldo Hall, Corvallis, OR, 97330. Email: \\ david.rothwell@oregonstate.edu
}

Shiyou Wu, PhD, MSW, Assistant Professor at School of Social Work, Arizona State University, 411 N. Central Ave., Suite 800, Phoenix, AZ, 85004. Email: shiyou.wu@asu.edu

Note. The authors thank participants at the Financial Consumer Agency of Canada’s 2016 National Research Symposium on Financial Literacy for comments and feedback on this study. 
The Impact of Financial Education Participation on Financial Knowledge and Efficacy: Evidence from the Canadian Financial Capability Survey 


\begin{abstract}
Very little is known about how participation in financial education affects cognitive outcomes such as financial knowledge and self-efficacy. We used two waves of the nationally representative Canadian Financial Capability Survey along with propensity score matching to compare outcomes between persons who had taken a financial education course to those who had not. After matching and adjusting for demographic and economic factors, financial education participants exhibited significantly higher financial knowledge and financial self-efficacy scores. Post-estimation analysis showed that higher overall financial knowledge scores of participants were at least partially driven by higher scores of men. There was no difference in knowledge scores for women across all age groups. Financial education participants had higher efficacy scores for both genders and across age. Future research into the impact of financial education ought to consider cognitive dimensions in addition to strictly behavioral and financial outcomes.
\end{abstract}

Keywords: financial education, financial knowledge, self-efficacy, Canada 
Rising economic inequality, decreased regulation, and increased personal responsibility are defining features of the past half-century. During this time financial products have become increasingly complex. Cash flow management and long term planning now involve an array of complex individual options and decisions. Recent estimates suggest that financial insecurity is widespread. For example, 39\% of Americans answered with certainty that they could afford a \$2,000 emergency expense (Lin et al., 2016). Just under half of Canadians own sufficient financial assets to maintain at the low income threshold for three months (Rothwell \& Robson, in press. early view). Overall, the evidence suggests that the changing marketplace, social institutions, and policies have combined to increase overall economic insecurity.

In efforts to promote economic well-being, governments have identified financial literacy as a policy priority. Several OECD countries now administer surveys to measure financial knowledge, literacy, and capability (OECD, 2013). In Canada, the federal government established a financial literacy task force in 2009 to promote financial literacy in the population. At the same time, as economic insecurity has increased, a number of financial education interventions have emerged. Financial education programs are featured in public schools, employment and community settings, and among anti-poverty interventions such as Individual Development Account (IDA) programs. The extent to which these programs improve financial knowledge and financial behaviors is of primary interest to policymakers.

In this study we use nationally representative Canadian data that includes information on participation in a financial education intervention. We match financial education participants to similar non-participants to estimate the impact of financial education. The outcomes of interest are financial knowledge and financial self-efficacy. Furthermore, we analyze how the impact of financial education varies across age and gender. 


\section{Financial knowledge and financial self-efficacy}

Financial literacy - also referred to as financial knowledge - is the ability to process economic information towards making informed decision about financial management (Lusardi \& Mitchell, 2014). Financial knowledge is consistently shown to be positively related to a variety of financial outcomes. For example, knowledge was associated with an increased likelihood of paying bills on time, budgeting, saving, and setting financial goals (Hilgert, Hogarth, \& Beverly, 2003). Individuals with low financial literacy are less likely to plan for retirement and hold lower level of wealth (Alessie, Van Rooij, \& Lusardi, 2011; Annamaria Lusardi \& Mitchell, 2007; Van Rooij, Lusardi, \& Alessie, 2012; Van Rooij, Lusardi, \& Alessie, 2011). Households with low financial literacy are less likely to invest in wealth-building assets such as stocks or bonds and are more likely to make financial mistakes (Van Rooij et al., 2011; Yoong, 2010). Financial knowledge is typically measured with a series of exam-style questions that are then scored as correct or incorrect. The more items correct, the higher the financial knowledge.

Self-assessment of one’s financial ability also matters. The idea of financial self-efficacy draws on the theory of self-efficacy developed by Bandura (1997). In his theory, behaviors are moderated by the cognitive expectations of those outcomes. According to Bandura, efficacy expectations are, "the conviction(s) that one can successfully execute the behavior required to produce the outcomes” (p. 193). Financial self-efficacy is thus the extension of efficacy to the area of financial management and involves understanding patterns of attitudes, beliefs, and confidence in relation to financial decisions and behaviors (Taylor, 2011). Previous research has shown that a standard deviation increase in financial self-efficacy was associated with an eight percentage point increase in the probability of emergency savings (Babiarz \& Robb, 2014). 
Others have shown that financially self-efficacy mediated the relationship between financial knowledge and behaviors such as post-secondary education savings (Rothwell, Khan, \& Cherney, 2016). Importantly, there are theoretical and empirical reasons for considering financial self-efficacy distinct from objective financial knowledge (Danes \& Haberman, 2007; Xiao, Chen, \& Chen, 2014). While most interventions to build financial literacy focus on delivering knowledge and ignore self-efficacy, some innovative programs are experimenting with the idea (Loke, Choi, \& Libby, 2015).

\section{Financial education}

In the context of individuals assuming increasing personal responsibility for their finances there is growing evidence of low financial literacy. In response, a number of interventions have been developed to increase financial knowledge, referred to hereafter as financial education interventions. Financial education includes any program that aims to change knowledge, attitudes, and behaviors of individuals in relation to their finances (Fox, Bartholomae, \& Lee, 2005). Financial education usually takes place in schools, community, and workplace settings and across a range of population groups (Walstad et al., 2017). The aims of financial education courses vary widely. Broadly speaking, financial education aims to (1) improve personal finances and budgeting, (2) improve retirement planning and saving, and (3) prepare for home buying and home ownership (Fox et al., 2005). High-level federal efforts have sought to expand financial knowledge. In the US, the Consumer and Financial Protection Bureau launched the Your Money, Your Goals educational toolkit as a structured set of resources to help social services, community, and legal aid workers educate clients about finances. The Financial and Consumer Agency of Canada (FCAC) has recently developed a comparable set of toolkits 
and modules designed to build financial knowledge for youth, young adults and adults (Financial Consumer Agency of Canada \& Canada, 2017).

Research on the impact of financial education stems mostly from evaluations of single interventions. Experimental research (Carpena, Cole, Shaprio, \& Zia, 2011) on financial education has shown mixed results. A much-cited meta-analysis of 90 effect sizes between financial education and financial behaviors such as savings, planning for retirement, cash flow management, etc. reported significant but very small effects $r^{2}=.001$ (Fernandes, Lynch, \& Netemeyer, 2014). Yet, others argue that each intervention varies widely depending on target group and goals and that impacts need to be evaluated based on economic circumstances of the study participant (Lusardi \& Mitchell, 2014; Walstad et al., 2017) and that financial education has potential (Collins \& O’Rourke, 2010). On financial knowledge, one study showed that financial education had across the board significant improvements on financial knowledge among high school students (Walstad, Rebeck, \& MacDonald, 2010). Another study showed that online financial education was associated with increased knowledge (Collins \& Urban, 2016). Despite these few studies on targeted populations, the influence of financial education on broader population-level financial knowledge and financial self-efficacy has been relatively understudied.

\section{Age and finances}

With chronological age we can expect financial knowledge and financial self-efficacy to change. On average, older people have higher financial knowledge than younger people. At each stage of the life course the financial focus tends to shift. Home ownership, planning for postsecondary education costs, and retirement are key financial periods that have implications for financial education (Walstad et al., 2017). And, available data suggested financial knowledge 
varies across age. Persons 55 to 64 years of age scored 68\% of financial knowledge questions correctly compared to 64\% among the 18 to 24 age group (Keown, 2011). In a U.S. sample with five knowledge questions, the 55 and older group averaged 3.6 correct answers compared to 2.6 correct for the 18 to 34 age bracket (Lin et al., 2016). The relationship between age and financial self-efficacy is less clear. Some have raised concerned about a financial knowledge gap, where older adults overestimate their financial knowledge in greater frequency than younger adults (Finke, Howe, \& Huston, 2016; Khan, Rothwell, Cherney, \& Sussman, 2017).

\section{Gender and finances}

In addition to age, variation in financial knowledge is driven highly by sex. Recent evidence suggests that older men are more knowledgeable than older women (Lusardi \& Mitchell, 2014) and the patterns hold across of number of countries (Bucher-Koenen, Lusardi, Alessie, \& Van Rooij, 2017). Women report less financial satisfaction and are less likely to have emergency savings (Babiarz \& Robb, 2014; Xiao et al., 2014). There is an active debate seeking to explain why women consistently score lower on financial knowledge and related outcomes. Whether or not women learn about financial matters in different ways from men remains to be seen. Nevertheless, the relatively low financial knowledge levels observed for women suggest that more work is needed to understand how they respond to financial education.

\section{Research questions}

This study on the impact of financial education is important in the context of expanding financial education interventions. We address a number of gaps in the literature. Whereas most assessments emerge from single interventions (see the studies in Fernandes et al., 2014), we examine a global indicator of financial education. Our indicator includes financial education interventions that take place in a variety of settings, e.g., schools, workplace, community 
settings, etc. Next, instead of examining behavioral outcomes such as savings and retirement planning, we focus on financial knowledge and financial self-efficacy. To date, little is known about the potential impact of financial education on these cognitive dimensions that are positively correlated with downstream financial behaviors. We assume that most, if not all, financial education interventions aim explicitly or tacitly to improve knowledge and efficacy regarding financial systems, cash flow management, and savings. Therefore, we ask the following research questions:

(1) What is the association between financial education and financial knowledge? What is the association between financial education and financial self-efficacy?

Holding other factors constant, we expect to observe higher financial knowledge and selfefficacy scores for individuals who participated in financial education courses. Building on the first research question, we then disaggregate our results across the age distribution.

(2) How do the associations found in research question 1 vary by age?

For working age adults, the majority of financial education interventions target retirement (Walstad et al., 2017). As such, assuming a positive relationship (research question 1), we expect the financial knowledge and self-efficacy scores to increase with age.

Last, we focus the inquiry on gender. This question builds on the consistent finding that women have lower levels of financial knowledge and efficacy and may be less responsive than males to financial education interventions (Lusardi \& Mitchell, 2014).

(3) How do the associations found in research question 1 vary by age and gender? While the financial knowledge and self-efficacy of women is lower than men's, we do not know how financial education might be associated with difference levels of knowledge and efficacy for women and men. On one hand, if financial education is effective, we would expect 
participation to narrow and perhaps erase gender gaps in the outcomes. On the contrary, women may experience less impact of financial education for the same reasons that cause women to have lower financial knowledge and efficacy. And thus the gaps in financial knowledge would be no different across participants and non-participants.

\section{Method}

\section{Data}

This study relies on two waves of the Canadian Financial Capability Surveys (CFCS 2009 and CFCS 2014). The CFCS is a national representative survey data conducted by the Statistics Canada, and sponsored by Human Resources and Skills Development Canada, Finance Canada and the Financial Consumer Agency of Canada (Statistics Canada, 2014). By using a cross-sectional, stratified multi-stage design and Random Digit Dialing (RDD) frame of a probability sampling method, the CFCS 2009 survey had a total sample size of 15,519 participants, whereas the CFCS 2014 survey contains 6,685 participants who were living in Canada and aged 18 years or above at the time of conducting the survey. Full-time residents of institutions and residents of the Yukon, Northwest Territories and Nunavut were not included in the surveys. We pooled the CFCS 2009 data and CFCS 2014 data for analysis $(N=22,204)$. The final analytic sample of this study reduced to 19,753 given missing values.

\section{Measurement}

Dependent variables. This study includes two dependent variables: objective financial knowledge and financial self-efficacy. Objective financial knowledge (or financial literacy) was measured with a 14-item scale, including questions asking participants to answer whether or not $(1=$ correct; 0 = incorrect $)$ they know the objective financial knowledge. Example items included, "Who insures your stocks in the stock market: The National Deposit Insurance 
Corporation (1/0); The Securities and Exchange Commission (1/0); The Bank of Canada (1/0)”. Responses for the 14 items were summed, with higher values indicating a higher level of objective financial knowledge. This scale had an acceptable internal consistency, with the Cronbach’s $\alpha$ equals 0.69 .

The second dependent variable was financial self-efficacy, which was measured with a five-item Likert scale. Participants were asked to rate their self-perceived levels of financial selfefficacy, including one overall abilities of financial knowledge and four specific domains such as keeping track, making ends meet, shopping around, and staying informed. Responses used a 4point scale (1=lower to 4=higher). Responses for the five items were summed, with higher values indicating a higher level of financial self-efficacy. This scale had an acceptable internal consistency, with the Cronbach’s $\alpha$ equals 0.75 .

Independent variables. The key independent variable of this study is financial education, which was a dichotomous indicator of having taken a course to increase knowledge of financial matters in past five years. For the pooled data, about $11 \%(n=2,275)$ of participants had indicated they had taken a financial education course.

Control variables. We separated the control variables into two groups. The first, demographic grouping, consisted of gender, family structure, immigrant status, and age. Gender was a dichotomous variable $(1=$ male; $0=$ female $)$. Family structure was dummy coded based on the following seven categories: married without children, living common law with children, living common law without children, divorced and separated with children, divorced and separated without children, single with children, single without children (reference group = married with children). Immigration status was a dichotomous variable $(1=$ immigrant, $0=$ 
Canadian). Chronological age included six mutually exclusive ordinal categories: 18-24; 25-34;

35-44; 45-54; 55-64; and 65 and over.

The second set of control variables, labeled economic grouping, included education, employment, and income. Participants' education level was recoded as four dummy variables: some college, trade technical school, university degree, graduate degree (reference group = high school or less). Employment status was coded as three dummy variables: self-employed, unemployed, retired, student or unemployed but not looking for job or unpaid household work (reference group = Full time and formally employed). Income level was coded as four dummy variables based on the Quintile cut off values: Quintile 2 to Quintile 5 (reference group = Quintile 1).

\section{Analytical strategy}

We first conducted a descriptive data analysis by the two groups (received financial education course vs. not received financial education courses) to understand any observable differences between financial education participants and non-participants. To be nationally representative, all analyses used the probability survey weights provided by Statistics Canada. Given the cross-sectional design of this survey, propensity score matching (PSM) was adopted so that the sample selection bias could be reduced, and the two groups were comparable (Guo \& Fraser, 2014).

Propensity score full matching was chosen to balance the data because full matching can maximize the number of available cases for the analysis (Rosenbaum \& Rubin, 1983). We used three steps of conducting PSM: First, logistic regression was used to predict each participant’s probability (i.e., propensity score) of receiving financial education based on all the control variables that were introduced. Second, 0.01 was used as the matching caliper, which means each 
participant who had ever received financial education was then matched with all the available counterparts (i.e., not ever received financial education) with the closed propensity scores within the 0.01 caliper. In addition, we limited the matching in the common support region with overlapped propensity scores. Last, balance checks on all the control variables before and after matching was conducted to ensure the two groups were well balanced.

Based on the balanced data after PSM, OLS regression was used to examine the association between the outcome variables and financial education. We controlled for different labor market and social welfare policies that vary by province with province and year dummy codes $(1=2008 ; 0=2014)$. For each outcome, we constructed three models that proceeded in stepwise fashion. Model (1) was the outcome regressed upon financial education only. The financial education coefficient from this model could be considered the Average Treatment Effect. Next, we added the demographic covariates (i.e., gender, age, education levels, employment status, family structures, immigrant status, provinces, and survey year) for Model (2). Last, the economic covariates (i.e., income levels) were added to the Model (3). The hierarchical modeling procedure was chosen to purposefully investigate the change in the financial education coefficient upon adding demographic and economic covariates. To address research question three, we plotted the predicted outcome scores from Model 3 across age groups for both genders. All analyses were conducted using Stata 13.1 for Windows.

\section{Results}

\section{Descriptive results}

As a starting point, we plotted the kernel density distributions of financial knowledge and financial self-efficacy across financial education groups in Figure 1. The distribution of financial knowledge reveals that financial education participants reported higher knowledge scores. More 
specifically, at lower points in the distribution the non-financial education group was more prevalent. As scores increased to around the mean overall, the balance shifted toward dominance by the financial education group. A similar pattern was also observed for financial self-efficacy, although the shift occurs after the overall mean of 13.42 .

[insert Figure 1 about here]

Table 1 column (a) shows the descriptive statistics for each variable based on the pooled data. The mean value of the objective knowledge scale was $8.68(S D=2.83)$, whereas the mean score of the financial self-efficacy scale was $13.42(S D=3.35)$. About $11 \%$ of participants had ever taken a course to increase knowledge of financial matters in past five years. The sample had slightly less females (48\%) than males (53\%). About 8\% participants aged 18-24, 15\% were between 25-34, 19\% were between 35-44, 21\% were between 45-54, 20\% were between 55-64, and 18\% were older than 65 years. The majority (79\%) of participants had some college education or above, about two third (62\%) of participants were full-time employed, about one third (34\%) of participants were married with children, and about 16\% participants were immigrants (see more details on Table 1 column (a)).

[insert Table 1 about here]

Table 1 column (b) shows that most covariates had significant differences between participants who never received financial education versus participants who did receive financial education. However, after PSM (see Table 1 column (c)), all these significant group differences had been removed, indicating these two groups were well-balanced. Based on the balanced data, we proceeded based on the assumption that differences in outcomes between these two groups were the results of receiving financial education rather than other observed indicators.

\section{Post-Matching Regression Analyses Results}


To test the effects of financial education on financial self-efficacy and objective financial knowledge, we adopted a three-model hierarchical approach. The OLS regression results with marginal coefficients of the predicted scores were presented in Table 2. The upper section of column (1) shows the marginal coefficient estimation of model (1) which regressed financial self-efficacy scores on the financial education only. Result shows that participants who had ever received financial education courses in past five years had a predicted efficacy score of 14.62 units $(p<.001)$, which was statistically significantly higher than their counterparts who had not completed education (13.26). The lower section of column (1) shows the marginal coefficient estimation of model (1) which regressed objective financial knowledge scores on the financial education only. Result shows that participants who had ever received financial education had significant higher predicted objective financial knowledge scores 9.54 units $(p<.001)$, compared with these who had not received financial education courses in the past five years (9.12).

[insert Table 2 about here]

The upper section of column (2) on table 2 shows the marginal coefficient estimation of model (2) which regressed financial self-efficacy scores on the financial education and the demographic covariates. Participants who had ever received financial education courses in past five years had significant higher predicted financial self-efficacy scores by 14.62 units ( $p$ $<$.001), compared with their counterparts. The lower section of column (2) shows that participants who had ever received financial education had significant higher predicted objective financial knowledge scores $(p<.001)$, compared with these who had not received financial education courses in the past five years.

The upper section of column (3) on table 2 shows the marginal coefficient estimation of model (3) which regressed financial self-efficacy scores on the financial education and the 
demographic covariates and the economic covariates. Result shows that participants who had ever received financial education courses in past five years had significant higher predicted financial self-efficacy scores $(p<.001)$, compared with their counterparts. The lower section of column (2) shows that participants who had ever received financial education had significant higher predicted objective financial knowledge scores $(p<.001)$, in relation individuals who had not received financial education courses in the past five years.

Turning to results across age and gender (research questions 2 and 3), Figure 2 plotted the regression-adjusted predicted financial knowledge and financial self-efficacy scores by age and gender. On objective knowledge, we see noticeable differences that relate to financial education. Namely, males aged 25 to 64 who had received financial education appeared to have meaningfully higher financial knowledge compared to those who had not received education (see Fig 2A). For women, the results are different: at no age is there a statistically significant difference between women who received financial education compared to women who had not (see the overlapping error bars at each age category in Fig 2B). By placing the scores on the same scale, Figure 2 puts the differences across gender in perspective. For example, the financial knowledge scores of men who did not participate in financial education had higher financial knowledge scores than women in a comparable age bracket who had taken financial education. The pattern of self-efficacy scores reveals relatively larger differences across treatment groups. For both men and women, across age groups, financial education participants scored higher on self-efficacy measures.

[insert Figure 2 about here] 


\section{Discussion}

Research on financial education has used mostly single site case study evaluations and focused on financial behaviors. In this observational study using national survey data for Canada, we compare individuals who participated in financial education to those who had not. Specifically, we expand the knowledge base by examining non-behavioral outcomes financial knowledge and financial efficacy. Our propensity score matching analyses suggest that financial education participants had higher financial knowledge and self-efficacy scores than nonparticipants. Further, we add to the ongoing debates on how financial education results vary across age and gender.

In comparing the outcomes of financial knowledge and financial self-efficacy, financial education participation appears to be more influential for the latter. Financial education alone explained a much greater proportion of the variation in financial self-efficacy than financial knowledge (see Table 2, model 1). Whereas other studies have shown that financial education participation was positively related to higher knowledge scores (see e.g., Walstad et al., 2010), we suspect the potential impact on financial knowledge may fade over time. Without temporal information on the timing of the education in relation to the knowledge scores we cannot examine this hypothesis. Future research that includes multiple measurements over time would provide insight into these possible explanations.

In comparison to the economic characteristics (employment, human capital, and income), the demographic variables explained more variation in the outcomes. The change in $R^{2}$ from base model to model 2 was uniformly greater than the change from model 2 to model 3 (that which included the economic information). And, the economic variables explain more for financial knowledge: the addition of economic variables roughly double the $R^{2}$ compared to a $36 \%$ 
increase for financial self-efficacy. Among the economic variables, it seems that human capital is the most important for financial knowledge and employment status is an important determinant of financial self-efficacy (see Appendix).

This study improves our understanding of gender gaps in financial knowledge. For the first time with national-level data, we provide evidence that financial education was associated with higher financial knowledge among men but not women, after adjusting for a variety of demographic and economic characteristics. For both men and women, financial knowledge scores adhered to an inverse u-shaped pattern with lower scores for younger, highest scores for middle age, and lower scores for the older groups. However, there was no difference for women who had financial education training (see Figure 2B). To explore a gender bias in financial education access we conducted post-hoc bivariate and multivariate results of participation (not shown). We found that men were no more likely to have taken financial education than women. As a result, it seems that access to financial education is not exacerbating the gendered financial knowledge gap. At least according to our global measure of any financial education, results suggest that financial education may not reduce inequalities in financial knowledge scores.

\section{Limitations}

The two most important limitations in this study include a lack of knowledge about the type of financial education and when the financial education occurred in relation to the survey response. Both are not observed in the CFCS, but are needed to better understand the associations we report. Although this study used propensity score analysis to control selection bias, PSM cannot rule out unobserved variables that may influence treatment effects. With unobserved variables we expect the estimates to be biased either up or down. For example, estimates would be biased up if the financial education group was comprised of individuals with 
prior financial knowledge and motivation to learn. Alternatively, the treatment effect would be biased downwards if, for example, those who selected into financial education had lower than average knowledge and financial efficacy, or had knowledge levels and financial self-efficacy that did not change much for other reasons (i.e., mandated into the course). Lastly, our study does is not able to account for the social environment and institutions that shape the outcomes. For example, known factors that affect financial capability such as financial intuition access, trust, and safety were not measured.

\section{Implications}

Our findings of a potential positive impact of financial education have implications for service providers and policymakers. First, the conceptualization of impact should be broadened beyond the measurement of financial behaviors. Understanding the importance of financial education may go beyond observing financial behaviors. This assertion is based on evidence that higher financial knowledge and improved financial self-efficacy are associated with financial well-being (Xiao, Chen, \& Chen, 2014). Second, results showing heterogeneity of impact across gender and age suggest that interventions must be carefully consider these dimensions in planning. A growing body of research suggests that financial education needs to be timely and relevant to the participants. Tailoring financial education content to life stage and gender might achieve more impact. Specific attention should be paid toward building financial knowledge among women.

Based on the research design we cannot argue that financial education caused the financial knowledge and financial efficacy scores to increase. However, the differences we observed after matching are suggestive of an impact. If in fact there were any effects of financial education on these outcomes, we would necessarily observe them in such a study. The magnitude 
of difference between groups that we observe here serve as a comparison for future applied experimental studies on financial education. 


\section{References}

Alessie, R., Van Rooij, M., \& Lusardi, A. (2011). Financial literacy and retirement preparation in the Netherlands. Journal of Pension Economics \& Finance, 10(4), 527-545.

Babiarz, P., \& Robb, C. (2014). Financial literacy and emergency saving. Journal of Family and Economic Issues, 35(1). https://doi.org/10.1007/s10834-013-9369-9

Bandura, A. (1997). Self-efficacy: The exercise of control. New York: Freeman.

Bucher-Koenen, T., Lusardi, A., Alessie, R., \& Van Rooij, M. (2017). How financially literate are women? An overview and new insights. Journal of Consumer Affairs, 51(2), 255-283.

Carpena, F., Cole, S., Shaprio, J., \& Zia, B. (2011). Unpacking the causal chain of financial literacy (No. 5798). Washington, D.C.: World Bank. Retrieved from http://documents.worldbank.org/curated/en/2011/09/15084797/unpacking-causal-chainfinancial-literacy.

Collins, J. M., \& O’Rourke, C. (2010). Financial education and counseling—Still holding promise. Journal of Consumer Affairs, 44(3), 483-498.

Collins, J. M., \& Urban, C. (2016). The role of information on retirement planning: evidence from a field study. Economic Inquiry, 54(4), 1860-1872. https://doi.org/10.1111/ecin.12349

Danes, S. M., \& Haberman, H. (2007). Teen financial knowledge, self-efficacy, and behavior: A gendered view. Journal of Financial Counseling and Planning, 18(2).

Fernandes, D., Lynch Jr, J. G., \& Netemeyer, R. G. (2014). Financial literacy, financial education, and downstream financial behaviors. Management Science. Retrieved from http://pubsonline.informs.org/doi/abs/10.1287/mnsc.2013.1849 
Financial Consumer Agency of Canada, \& Canada, F. C. A. of. (2017). Your Financial Toolkit [education and awareness]. Retrieved September 18, 2017, from https://www.canada.ca/en/financial-consumer-agency/services/financial-toolkit.html

Finke, M. S., Howe, J. S., \& Huston, S. J. (2016). Old age and the decline in financial literacy. Management Science, 63(1), 213-230. https://doi.org/10.1287/mnsc.2015.2293

Fox, J., Bartholomae, S., \& Lee, J. (2005). Building the case for financial education. Journal of Consumer Affairs, 39(1), 195-214.

Guo, S., \& Fraser, M. W. (2014). Propensity score analysis: Statistical methods and applications (Vol. 11). Sage Publications.

Hilgert, M., Hogarth, J., \& Beverly, S. (2003). Household financial management: The connection between knowledge and behavior. Federal Reserve Bulletin, 89(7), 309-322.

Keown, L.-A. (2011). The financial knowledge of Canadians. Canadian Social Trends, 11(008), 30-39.

Khan, M. N., Rothwell, D. W., Cherney, K., \& Sussman, T. (2017). Understanding the financial knowledge gap: A new dimension of inequality in later life. Journal of Gerontological Social Work, O(0), 1-17. https://doi.org/10.1080/01634372.2017.1317311

Lin, J., Bumcrot, C., Ulicny, T., Lusardi, A., Mottola, G., Kieffer, C., \& Walsh, G. (2016). Financial Capability in the United States 2016. FINRA Investor Education Foundation. Retrieved from http://www.usfinancialcapability.org/downloads/NFCS_2015_Report_Natl_Findings.pdf Loke, V., Choi, L., \& Libby, M. (2015). Increasing youth financial capability: an evaluation of the mypath savings initiative. Journal of Consumer Affairs, 49(1), 97-126. https://doi.org/10.1111/joca.12066 
Lusardi, A., \& Mitchell, O. (2014). The economic importance of financial literacy: Theory and evidence. Journal of Economic Literature, 52(1), 5-44. https://doi.org/10.1257/jel.52.1.5

Lusardi, A., \& Mitchell, O. S. (2007). Financial literacy and retirement planning: New evidence from the Rand American Life Panel. Michigan Retirement Research Center Research Paper No. WP, 157. Retrieved from http://papers.ssrn.com/sol3/papers.cfm?abstract_id=1095869

OECD. (2013). Advancing national strategies for financial education. Paris: OECD. Retrieved from www.oecd.org/finance/financial-education/G20_OECD_NSFinancialEducation.pdf

Rosenbaum, P. R., \& Rubin, D. B. (1983). The central role of the propensity score in observational studies for causal effects. Biometrika, 70(1), 41-55.

Rothwell, D. W., Khan, M. N., \& Cherney, K. (2016). Building financial knowledge is not enough: financial self-efficacy as a mediator in the financial capability of low-income families. Journal of Community Practice, 24(4), 368-388.

https://doi.org/10.1080/10705422.2016.1233162

Rothwell, D. W., \& Robson, J. (in press. early view). The prevalence and composition of asset poverty in Canada: 1999, 2005, and 2012. International Journal of Social Welfare. https://doi.org/10.1111/ijsw.12275

Statistics Canada. (2014). Canadian Financial Capability Survey (CFCS). Retrieved August 26, 2014, from http://www23.statcan.gc.ca/imdb/p2SV.pl?Function=getSurvey\&SDDS=5159 Taylor, M. (2011). Measuring financial capability and its determinants using survey data. Social Indicators Research, 102(2), 297-314.

Van Rooij, M. C., Lusardi, A., \& Alessie, R. J. (2012). Financial literacy, retirement planning and household wealth. The Economic Journal, 122(560), 449-478. 
Van Rooij, M., Lusardi, A., \& Alessie, R. (2011). Financial literacy and stock market participation. Journal of Financial Economics, 101(2), 449-472.

Walstad, W., Rebeck, K., \& MacDonald, R. A. (2010). The effects of financial education on the financial knowledge of high school students. Journal of Consumer Affairs, 44(2), 336357. https://doi.org/10.1111/j.1745-6606.2010.01172.x

Walstad, W., Urban, C., J. Asarta, C., Breitbach, E., Bosshardt, W., Heath, J., ... Xiao, J. J. (2017). Perspectives on evaluation in financial education: Landscape, issues, and studies. The Journal of Economic Education, 48(2), 93-112.

Xiao, J. J., Chen, C., \& Chen, F. (2014). Consumer financial capability and financial satisfaction. Social Indicators Research, 118(1), 415-432. https://doi.org/10.1007/s11205-013-0414-8

Yoong, J. (2010). Financial illiteracy and stock market participation: Evidence from the RAND American Life Panel. Retrieved from https://papers.ssrn.com/sol3/papers.cfm?abstract_id=1707523 
TABLE 1

Descriptive results and balance check before and after PSM

\begin{tabular}{|c|c|c|c|c|c|c|c|c|c|c|c|c|}
\hline \multirow[b]{3}{*}{ Dependent Variables } & \multicolumn{2}{|c|}{$\begin{array}{l}\text { (a) Pooled Data } \\
(\mathrm{n}=19,753)\end{array}$} & \multicolumn{5}{|c|}{$\begin{array}{l}\text { (b) Before Matching } \\
(\mathrm{n}=19,753)\end{array}$} & \multicolumn{4}{|c|}{$\begin{array}{l}\text { (c) After Full Matching } \\
(\mathrm{n}=17,987)\end{array}$} & \\
\hline & \multirow[b]{2}{*}{ Mean } & \multirow[b]{2}{*}{ SD } & \multicolumn{2}{|c|}{$\begin{array}{c}\text { Yes } \\
(\mathrm{n}=2,164)\end{array}$} & \multicolumn{2}{|c|}{$\begin{array}{c}\text { Yes } \\
(\mathrm{n}=2,164)\end{array}$} & \multirow[b]{2}{*}{$p$} & \multicolumn{2}{|c|}{$\begin{array}{c}\text { Yes } \\
(\mathrm{n}=2,153)\end{array}$} & \multicolumn{2}{|c|}{$\begin{array}{c}\text { Yes } \\
(\mathrm{n}=2,153)\end{array}$} & \multirow[b]{2}{*}{$p$} \\
\hline & & & Mean & SD & Mean & SD & & Mean & SD & Mean & SD & \\
\hline Objective knowledge & 8.68 & 2.83 & & & & & & & & & & \\
\hline Financial self-efficacy & 13.42 & 3.35 & & & & & & & & & & \\
\hline \multicolumn{13}{|l|}{ Independent Variables } \\
\hline Financial education & 0.11 & 0.31 & & & & & & & & & & \\
\hline Male & 0.48 & 0.50 & 0.47 & 0.50 & 0.48 & 0.50 & & 0.47 & 0.50 & 0.48 & 0.50 & \\
\hline \multicolumn{13}{|l|}{ Age } \\
\hline $18-24$ & 0.08 & 0.26 & 0.19 & 0.39 & 0.06 & 0.24 & $* * *$ & 0.18 & 0.39 & 0.17 & 0.38 & \\
\hline $25-34$ & 0.15 & 0.36 & 0.23 & 0.42 & 0.14 & 0.35 & $* * *$ & 0.23 & 0.42 & 0.23 & 0.42 & \\
\hline $35-44$ & 0.19 & 0.39 & 0.23 & 0.42 & 0.19 & 0.39 & *** & 0.23 & 0.42 & 0.24 & 0.43 & \\
\hline $45-54$ & 0.21 & 0.41 & 0.19 & 0.39 & 0.22 & 0.41 & ** & 0.19 & 0.39 & 0.19 & 0.39 & \\
\hline $55-64$ & 0.20 & 0.40 & 0.12 & 0.32 & 0.20 & 0.40 & $* * *$ & 0.12 & 0.33 & 0.12 & 0.33 & \\
\hline 65 over & 0.18 & 0.38 & 0.05 & 0.21 & 0.19 & 0.39 & $* * *$ & 0.04 & 0.20 & 0.05 & 0.21 & \\
\hline \multicolumn{13}{|l|}{ Education level } \\
\hline High school or less & 0.21 & 0.41 & 0.07 & 0.25 & 0.23 & 0.42 & $* * *$ & 0.07 & 0.25 & 0.06 & 0.24 & \\
\hline Some college & 0.17 & 0.37 & 0.14 & 0.35 & 0.17 & 0.38 & ** & 0.14 & 0.35 & 0.15 & 0.35 & \\
\hline Trade technical school & 0.18 & 0.38 & 0.18 & 0.39 & 0.18 & 0.38 & & 0.18 & 0.39 & 0.18 & 0.38 & \\
\hline University degree & 0.23 & 0.42 & 0.27 & 0.44 & 0.23 & 0.42 & $* * *$ & 0.27 & 0.44 & 0.27 & 0.44 & \\
\hline Grad degree & 0.22 & 0.41 & 0.34 & 0.47 & 0.20 & 0.40 & $* * *$ & 0.34 & 0.47 & 0.34 & 0.47 & \\
\hline \multicolumn{13}{|l|}{ Employment status } \\
\hline Employed & 0.62 & 0.49 & 0.74 & 0.44 & 0.61 & 0.49 & *** & 0.74 & 0.44 & 0.76 & 0.43 & \\
\hline Unemployed & 0.13 & 0.33 & 0.09 & 0.28 & 0.13 & 0.34 & $* * *$ & 0.09 & 0.28 & 0.09 & 0.28 & \\
\hline Retired & 0.22 & 0.41 & 0.07 & 0.25 & 0.24 & 0.42 & $* * *$ & 0.07 & 0.25 & 0.06 & 0.24 & \\
\hline Student - not seeking jobs & 0.04 & 0.19 & 0.11 & 0.31 & 0.03 & 0.16 & $* * *$ & 0.11 & 0.31 & 0.10 & 0.29 & \\
\hline \multicolumn{13}{|l|}{ Family Structure } \\
\hline Fam Married w/ children & 0.19 & 0.40 & 0.23 & 0.42 & 0.19 & 0.39 & $* * *$ & 0.23 & 0.42 & 0.23 & 0.42 & \\
\hline Married w/o children & 0.34 & 0.47 & 0.23 & 0.42 & 0.35 & 0.48 & $* * *$ & 0.23 & 0.42 & 0.23 & 0.42 & \\
\hline Common law w/ children & 0.04 & 0.20 & 0.04 & 0.20 & 0.04 & 0.20 & & 0.04 & 0.20 & 0.04 & 0.20 & \\
\hline Common law w/o children & 0.06 & 0.24 & 0.05 & 0.23 & 0.06 & 0.24 & & 0.06 & 0.23 & 0.06 & 0.23 & \\
\hline Divorced sep w/ children & 0.03 & 0.18 & 0.04 & 0.19 & 0.03 & 0.17 & & 0.04 & 0.19 & 0.04 & 0.19 & \\
\hline Divorced sep w/o children & 0.11 & 0.31 & 0.08 & 0.27 & 0.11 & 0.31 & $* * *$ & 0.08 & 0.27 & 0.08 & 0.27 & \\
\hline Single with children & 0.04 & 0.20 & 0.08 & 0.27 & 0.04 & 0.19 & *** & 0.08 & 0.27 & 0.07 & 0.26 & \\
\hline Single without children & 0.18 & 0.39 & 0.26 & 0.44 & 0.17 & 0.38 & $* * *$ & 0.26 & 0.44 & 0.25 & 0.43 & \\
\hline Immigrant & 0.16 & 0.36 & 0.18 & 0.38 & 0.15 & 0.36 & $* *$ & 0.18 & 0.38 & 0.18 & 0.38 & \\
\hline \multicolumn{13}{|l|}{ Income Level } \\
\hline Quintile 1 & 0.20 & 0.40 & 0.13 & 0.34 & 0.21 & 0.41 & $* * *$ & 0.13 & 0.34 & 0.13 & 0.33 & \\
\hline Quintile 2 & 0.21 & 0.41 & 0.17 & 0.38 & 0.21 & 0.41 & $* * *$ & 0.18 & 0.38 & 0.17 & 0.38 & \\
\hline Quintile 3 & 0.21 & 0.41 & 0.20 & 0.40 & 0.21 & 0.41 & & 0.20 & 0.40 & 0.20 & 0.40 & \\
\hline Quintile 4 & 0.20 & 0.40 & 0.23 & 0.42 & 0.19 & 0.39 & $* * *$ & 0.23 & 0.42 & 0.23 & 0.42 & \\
\hline Quintile 5 & 0.18 & 0.39 & 0.27 & 0.45 & 0.17 & 0.38 & $* * *$ & 0.27 & 0.44 & 0.27 & 0.44 & \\
\hline Province & & & & & & & & & & & & \\
\hline Province1 & 0.18 & 0.39 & 0.15 & 0.36 & 0.19 & 0.39 & $* * *$ & 0.15 & 0.36 & 0.15 & 0.36 & \\
\hline Province2 & 0.20 & 0.40 & 0.17 & 0.37 & 0.21 & 0.41 & $* * *$ & 0.17 & 0.37 & 0.17 & 0.37 & \\
\hline Province3 & 0.27 & 0.44 & 0.29 & 0.45 & 0.26 & 0.44 & $*$ & 0.29 & 0.45 & 0.29 & 0.45 & \\
\hline Province4 & 0.25 & 0.43 & 0.29 & 0.45 & 0.25 & 0.43 & $* * *$ & 0.29 & 0.45 & 0.28 & 0.45 & \\
\hline Province5 & 0.10 & 0.29 & 0.11 & 0.31 & 0.09 & 0.29 & & 0.11 & 0.31 & 0.11 & 0.31 & \\
\hline Year2008 & 0.70 & 0.46 & 0.77 & 0.42 & 0.69 & 0.46 & $* * *$ & 0.77 & 0.42 & 0.77 & 0.42 & \\
\hline
\end{tabular}

Notes: Chi-square (for categorical variables) and t tests (for continuous variables) were used to test significant group differences. ${ }^{* * *} p<0.001,{ }^{* *} p<0.01,{ }^{*} p<0.05$. p value with blank means variable has no significant difference between the two groups. 
TABLE 2

Effects of financial education on financial self-efficacy and objective knowledge

\begin{tabular}{|c|c|c|c|}
\hline Model & (1) & (2) & (3) \\
\hline Financial Self-efficacy & $\begin{array}{c}\text { Predicted score } \\
\text { (Robust S.E.) }\end{array}$ & $\begin{array}{c}\text { Predicted score } \\
\text { (Robust S.E.) }\end{array}$ & $\begin{array}{c}\text { Predicted score } \\
\text { (Robust S.E.) }\end{array}$ \\
\hline Financial Education & $\begin{array}{c}14.616 * * * \\
(0.072)\end{array}$ & $\begin{array}{c}14.621^{* * * *} \\
(0.070)\end{array}$ & $\begin{array}{c}14.625^{* * * *} \\
(0.069)\end{array}$ \\
\hline \multicolumn{4}{|l|}{ Controls included } \\
\hline $\begin{array}{l}\text { Demographic } \\
\text { Economic }\end{array}$ & & $\mathrm{X}$ & $\begin{array}{l}X \\
X\end{array}$ \\
\hline$R^{2}$ & 0.042 & 0.116 & 0.150 \\
\hline Objective Knowledge & $\begin{array}{l}\text { Predicted score } \\
\text { (Robust S.E.) }\end{array}$ & $\begin{array}{c}\text { Predicted score } \\
\text { (Robust S.E.) }\end{array}$ & $\begin{array}{c}\text { Predicted score } \\
\text { (Robust S.E.) }\end{array}$ \\
\hline Financial Education & $\begin{array}{c}9.536 * * * \\
(0.058)\end{array}$ & $\begin{array}{c}9.541^{* * *} \\
(0.056)\end{array}$ & $\begin{array}{c}9.545^{* * *} \\
(0.055)\end{array}$ \\
\hline \multicolumn{4}{|l|}{ Controls } \\
\hline $\begin{array}{l}\text { Demographic } \\
\text { Economic }\end{array}$ & & $\mathrm{X}$ & $\begin{array}{l}X \\
X\end{array}$ \\
\hline$R^{2}$ & 0.006 & 0.084 & 0.159 \\
\hline
\end{tabular}

Notes. Predicted scores are produced from post-estimation margins command. Values represent the average predicted score on the outcome variable. Marginal coefficient estimation of all the covariates were omitted in the table. 

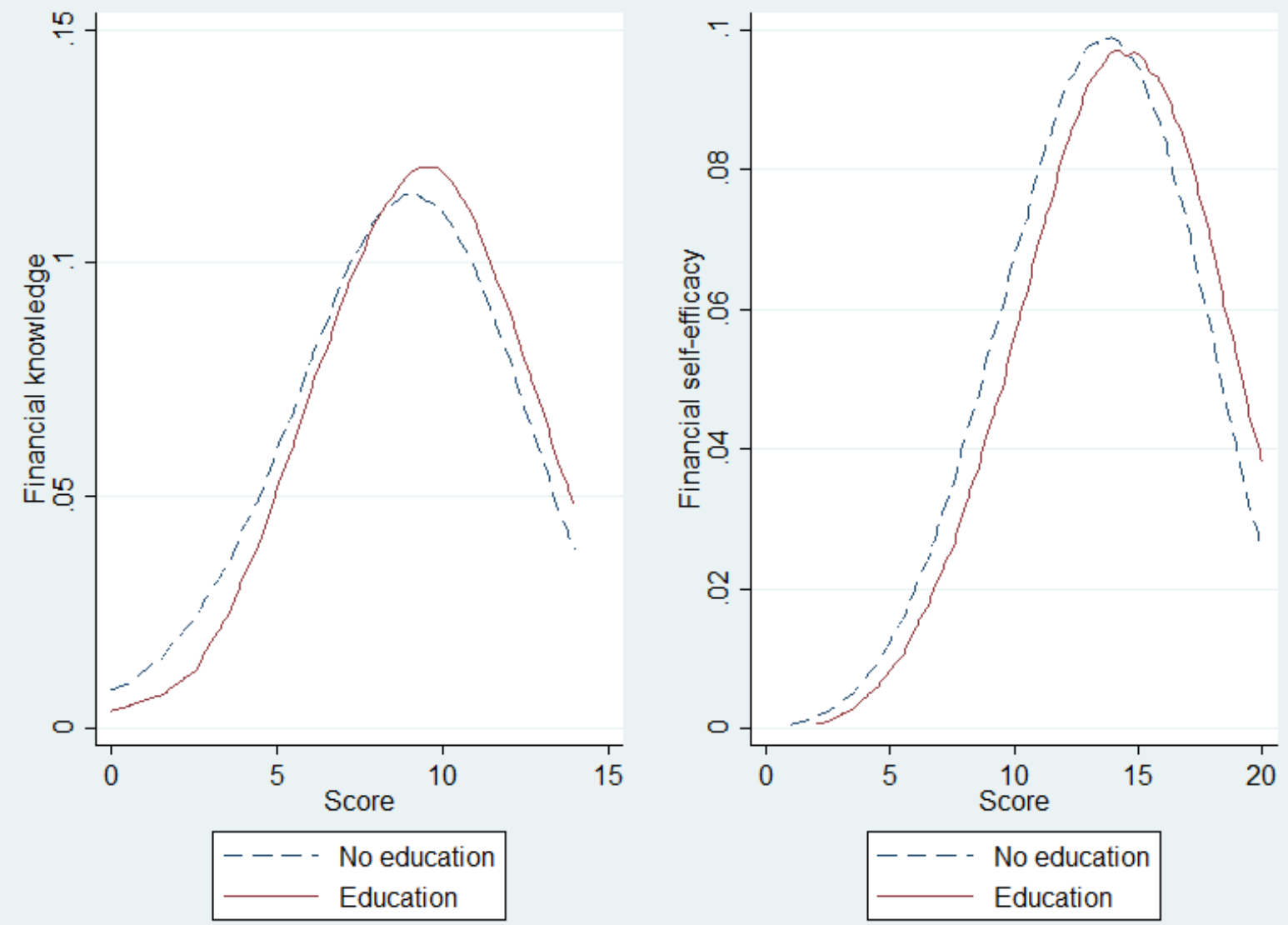

Figure 1. Kernel density plots of financial knowledge and financial self-efficacy across financial education. 
A

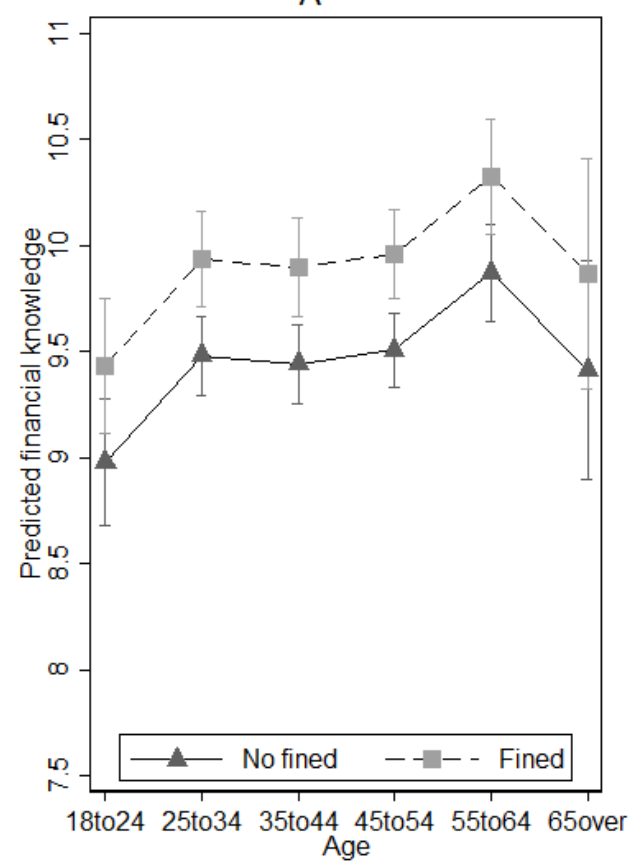

B
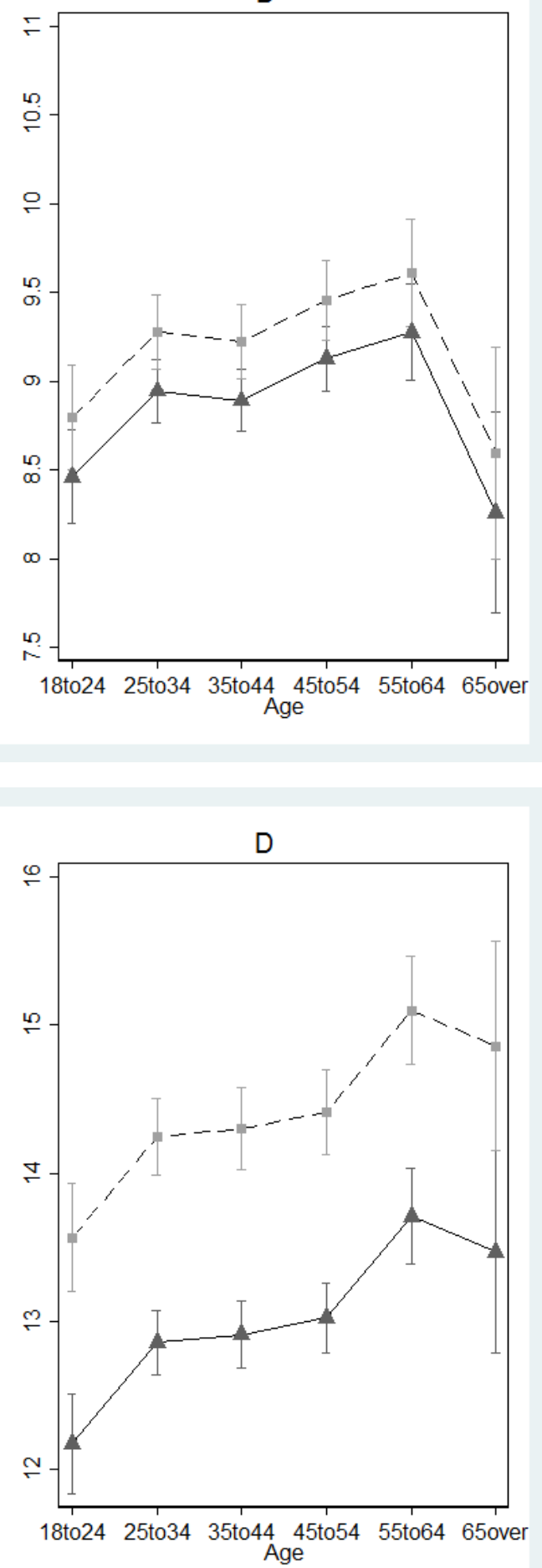

Figure 2. Regression-adjusted Predicted Financial Knowledge and Financial Self-Efficacy Across Age and Gender. Plots 2A and 2C represent males; plots 2B and 2D represent females. 
APPENDIX

Marginal coefficient estimation of all the covariates

\begin{tabular}{|c|c|c|c|c|c|c|}
\hline Covariates & $\begin{array}{c}(1) \\
\text { Financial } \\
\text { self-efficacy }\end{array}$ & $\begin{array}{c}(2) \\
\begin{array}{l}\text { Financial self- } \\
\text { efficacy }\end{array} \\
\end{array}$ & $\begin{array}{c}\text { (3) } \\
\begin{array}{c}\text { Financial self- } \\
\text { efficacy }\end{array} \\
\end{array}$ & $\begin{array}{c}(4) \\
\text { Objective } \\
\text { knowledge } \\
\end{array}$ & $\begin{array}{c}5) \\
\text { Objective } \\
\text { knowledge }\end{array}$ & $\begin{array}{c}(6) \\
\text { Objective } \\
\text { knowledge } \\
\end{array}$ \\
\hline Male & & $\begin{array}{c}0.71^{* * *} \\
{[0.559-0.867]}\end{array}$ & $\begin{array}{c}0.65 * * * \\
{[0.497-0.800]}\end{array}$ & & $\begin{array}{c}0.60 * * * \\
{[0.479-0.726]}\end{array}$ & $\begin{array}{c}0.57 * * * \\
{[0.450-0.688]}\end{array}$ \\
\hline $\begin{array}{l}\text { Age (ref.= 18-24) } \\
25-34\end{array}$ & & $0.97 * * *$ & $0.59 * * *$ & & $0.83^{* * *}$ & $0.49 * * *$ \\
\hline & & [0.699 - 1.246] & [0.306 - 0.880] & & [0.604 - 1.051] & [0.256 - 0.719] \\
\hline $35-44$ & & $\begin{array}{c}1.14 * * * \\
{[0.847-1.440]}\end{array}$ & $\begin{array}{c}0.68 * * * \\
{[0.368-0.989]}\end{array}$ & & $\begin{array}{c}0.82 * * * \\
{[0.587-1.059]}\end{array}$ & $\begin{array}{c}0.45^{* * *} \\
{[0.208-0.698]}\end{array}$ \\
\hline $45-54$ & & $\begin{array}{c}1.16^{* * *} \\
{[0.861-1.463]}\end{array}$ & $\begin{array}{c}0.76 * * * \\
{[0.449-1.070]}\end{array}$ & & $\begin{array}{c}0.86 * * * \\
{[0.621-1.106]}\end{array}$ & $\begin{array}{c}0.63 * * * \\
{[0.379-0.876]}\end{array}$ \\
\hline $55-64$ & & $\begin{array}{c}1.82 * * * \\
{[1.490-2.147]}\end{array}$ & $\begin{array}{c}1.36 * * * \\
{[1.014-1.716]}\end{array}$ & & $\begin{array}{c}1.16^{* * *} \\
{[0.889-1.437]}\end{array}$ & $\begin{array}{c}0.91 * * * \\
{[0.623-1.198]}\end{array}$ \\
\hline 65 over & & $\begin{array}{c}1.32 * * * \\
{[0.882-1.765]}\end{array}$ & $\begin{array}{c}0.87 * * \\
{[0.322-1.427]}\end{array}$ & & $\begin{array}{c}0.31 \\
{[-0.071-0.698]}\end{array}$ & $\begin{array}{c}0.17 \\
{[-0.299-0.636]}\end{array}$ \\
\hline $\begin{array}{l}\text { Education level } \\
\text { Some college }\end{array}$ & & & $0.49 * *$ & & & $0.62 * * *$ \\
\hline Trade technical school & & & $\begin{array}{c}{[0.135-0.845]} \\
0.55^{* *} \\
{[0.211-0.894]}\end{array}$ & & & $\begin{array}{c}{[0.332-0.905]} \\
1.26 * * * \\
{[0.982-1.530]}\end{array}$ \\
\hline University degree & & & $\begin{array}{c}1.01^{* * *} \\
{[0.678-1.337]}\end{array}$ & & & $\begin{array}{c}1.45^{* * *} \\
{[1.189-1.718]}\end{array}$ \\
\hline Grad degree & & & $\begin{array}{c}1.24 * * * \\
{[0.895-1.579]}\end{array}$ & & & $\begin{array}{c}2.09 * * * \\
{[1.816-2.359]}\end{array}$ \\
\hline $\begin{array}{l}\text { Employment status } \\
\text { Unemployed }\end{array}$ & & & $-0.35^{*}$ & & & $-0.33 * *$ \\
\hline Student - not seeking & & & $\begin{array}{c}{[-0.617--0.083]} \\
0.36 \\
{[-0.047-0.764]} \\
-0.59 * * * \\
{[-0.926--0.253]}\end{array}$ & & & $\begin{array}{c}{[-0.542--0.118]} \\
0.06 \\
{[-0.262-0.375]} \\
0.07 \\
{[-0.190-0.325]}\end{array}$ \\
\hline $\begin{array}{l}\text { Family Structure } \\
\text { Married w/o children }\end{array}$ & & $0.29 *$ & $0.32 * *$ & & -0.09 & -0.03 \\
\hline Common law w/ child & & $\begin{array}{c}{[0.048-0.531]} \\
-0.26 \\
{[-0.628-0.100]}\end{array}$ & $\begin{array}{c}{[0.081-0.556]} \\
-0.08 \\
{[-0.431-0.276]}\end{array}$ & & $\begin{array}{c}{[-0.277-0.105]} \\
-0.44^{* *} \\
{[-0.749--0.140]}\end{array}$ & $\begin{array}{c}{[-0.216-0.155]} \\
-0.18 \\
{[-0.476-0.114]}\end{array}$ \\
\hline Common law w/o child & & $\begin{array}{c}0.22 \\
{[-0.139-0.585]}\end{array}$ & $\begin{array}{c}0.36^{*} \\
{[0.004-0.710]}\end{array}$ & & $\begin{array}{c}-0.19 \\
{[-0.488-0.113]}\end{array}$ & $\begin{array}{c}0.00 \\
{[-0.282-0.291]}\end{array}$ \\
\hline Divorced sep w/ child & & $\begin{array}{c}-0.65 * * \\
{[-1.080--0.227]}\end{array}$ & $\begin{array}{c}-0.19 \\
{[-0.616-0.238]}\end{array}$ & & $\begin{array}{c}-0.14 \\
{[-0.444-0.163]}\end{array}$ & $\begin{array}{c}0.29 \\
{[-0.000-0.589]}\end{array}$ \\
\hline Divorced sep w/o child & & $\begin{array}{c}0.12 \\
{[-0.219-0.461]}\end{array}$ & $\begin{array}{c}0.48 * * \\
{[0.142-0.822]}\end{array}$ & & $\begin{array}{c}-0.11 \\
{[-0.370-0.149]}\end{array}$ & $\begin{array}{c}0.24 \\
{[-0.013-0.497]}\end{array}$ \\
\hline Single with children & & $\begin{array}{c}-0.86 * * * \\
{[-1.244--0.485]}\end{array}$ & $\begin{array}{c}-0.33 \\
{[-0.710-0.045]}\end{array}$ & & $\begin{array}{c}-0.82 * * * \\
{[-1.126--0.523]}\end{array}$ & $\begin{array}{c}-0.25 \\
{[-0.549-0.044]}\end{array}$ \\
\hline Single without children & & $\begin{array}{c}-0.62 * * * \\
{[-0.867--0.366]}\end{array}$ & $\begin{array}{c}-0.29 * \\
{[-0.538--0.041]}\end{array}$ & & $\begin{array}{c}-0.30 * * \\
{[-0.499--0.107]}\end{array}$ & $\begin{array}{c}-0.02 \\
{[-0.211-0.175]}\end{array}$ \\
\hline Immigrant & & $\begin{array}{c}-0.49 * * * \\
{[-0.708--0.276]}\end{array}$ & $\begin{array}{c}-0.41 * * * \\
{[-0.625--0.191]}\end{array}$ & & $\begin{array}{c}-1.19 * * * \\
{[-1.372--1.016]}\end{array}$ & $\begin{array}{c}-1.22 * * * \\
{[-1.391--1.042]}\end{array}$ \\
\hline $\begin{array}{l}\text { Income Level } \\
\text { Quintile } 2\end{array}$ & & & $0.40^{* *}$ & & & $0.39 * * *$ \\
\hline & & & [0.111 - 0.688] & & & [0.174 - 0.613] \\
\hline Quintile 3 & & & $\begin{array}{c}0.73 * * * \\
{[0.446-1.008]}\end{array}$ & & & $\begin{array}{c}0.64 * * * \\
{[0.424-0.854]}\end{array}$ \\
\hline Quintile 4 & & & $\begin{array}{c}0.79 * * * \\
{[0.506-1.080]}\end{array}$ & & & $\begin{array}{c}0.87 * * * \\
{[0.658-1.085]}\end{array}$ \\
\hline Quintile 5 & & & $\begin{array}{c}1.30 * * * \\
{[1.004-1.588]}\end{array}$ & & & $\begin{array}{c}1.08 * * * \\
{[0.853-1.298]}\end{array}$ \\
\hline Province & & -0.09 & -0.17 & & 0.14 & -0.01 \\
\hline
\end{tabular}




\begin{tabular}{|c|c|c|c|c|c|c|}
\hline \multicolumn{7}{|l|}{ Province 2} \\
\hline \multirow{3}{*}{ Province 3} & & {$[-0.350-0.167]$} & [-0.424 - 0.079] & & {$[-0.064-0.350]$} & {$[-0.215-0.190]$} \\
\hline & & -0.24 & $-0.38 * *$ & & $0.35 * * *$ & $0.21 *$ \\
\hline & & {$[-0.491-0.003]$} & {$[-0.625--0.143]$} & & [0.146 - 0.546] & {$[0.015-0.400]$} \\
\hline \multirow[t]{2}{*}{ Province 4} & & $-0.44 * * *$ & $-0.54 * * *$ & & $0.56 * * *$ & $0.51^{* * *}$ \\
\hline & & {$[-0.671--0.203]$} & {$[-0.774--0.316]$} & & {$[0.367-0.750]$} & [0.331 - 0.698] \\
\hline \multirow[t]{2}{*}{ Province 5} & & -0.13 & -0.23 & & $0.74 * * *$ & $0.67 * * *$ \\
\hline & & {$[-0.433-0.176]$} & {$[-0.528-0.073]$} & & [0.493 - 0.993] & [0.431 - 0.916] \\
\hline \multirow[t]{2}{*}{ year2008 } & & 0.04 & -0.08 & & 0.01 & $-0.22 * *$ \\
\hline & & {$[-0.142-0.215]$} & {$[-0.274-0.105]$} & & {$[-0.135-0.156]$} & {$[-0.368--0.065]$} \\
\hline \multirow[t]{2}{*}{ Constant } & $13.26^{* * *}$ & $12.37 * * *$ & $11.19 * * *$ & $9.14^{* * *}$ & $8.18^{* * *}$ & $6.43^{* * *}$ \\
\hline & $\begin{array}{c}{[13.185 \text { - }} \\
13.329]\end{array}$ & $\begin{array}{c}{[11.997 \text { - }} \\
12.745]\end{array}$ & $\begin{array}{c}{[10.680 \text { - }} \\
11.695]\end{array}$ & $\begin{array}{c}{[9.083-} \\
9.194]\end{array}$ & [7.873 - 8.494] & [6.021 - 6.832] \\
\hline Observations & 17,121 & 17,121 & 17,121 & 16,991 & 16,991 & 16,991 \\
\hline R-squared & 0.042 & 0.116 & 0.150 & 0.006 & 0.083 & 0.159 \\
\hline
\end{tabular}

